\title{
A salmonid cell line (TO) for production of infectious salmon anaemia virus (ISAV)
}

\author{
Heidrun I. Wergeland*, Ragnhild Aakre Jakobsen \\ Department of Fisheries and Marine Biology, University of Bergen, Bergen High Technology Center, 5020 Bergen, Norway
}

\begin{abstract}
A new cell line designated TO which provides a high yield of infectious salmon anaemia virus (ISAV) has been established. The cells originate from head kidney leukocytes isolated from Atlantic salmon and grow well at $20^{\circ} \mathrm{C}$ in EMEM with $5 \% \mathrm{CO}_{2}$ and without $\mathrm{CO}_{2}$ supplement in HMEM. The cells have at present been passed more than 150 times and no changes in morphology, growth or virus production have been observed. The virus infection results in cytopathic effects (CPE) within $9 \mathrm{~d}$, and the virus titre obtained from centrifuged and filtrated cell lysates, measured as $\mathrm{TCID}_{50}$, was about $10^{9.1} \mathrm{ml}^{-1}$. The virus isolated from lysates of infected cells by a sucrose gradient provided purified ISAV when examined by silver stained SDS-PAGE. Salmon injected with diluted virus supernatant showed mortalities, hematocrit values and clinical signs in accordance with infectious salmon anaemia.
\end{abstract}

KEY WORDS: Cell line $\cdot$ Salmon $\cdot$ Infectious salmon anaemia virus, ISAV $\cdot$ Fish virus

\section{INTRODUCTION}

The infectious salmon anaemia virus (ISAV) has caused severe losses in salmonid aquaculture in Norway since late 1997 in Canada (Bouchard et al. 1999, Lovely et al. 1999) and since 1998 in Scotland (Rodger et al. 1998). The virus has been identified as an orthomyxovirus-like virus (Falk et al. 1997, Mjaaland et al. 1997).

A cell line, SHK-1, derived from head kidney cells of Atlantic salmon Salmo salar L. has been established to support replication of ISAV (Dannevig et al. 1995a,b). ISAV can also replicate in other cell lines like CHSE214 derived from Chinook salmon Oncorhynchus tshawytscha (Bouchard et al. 1999, Lovely et al. 1999, Kibenge et al. 2000) and AS derived from visceral organs of Atlantic salmon S. salar L. (Sommer \& Mennen 1997). It has been possible to examine samples from diseased fish by use of the SHK-1 cell line. The clinical diagnosis of ISA has been supported by

\footnotetext{
*E-mail: heidrun.wergeland@ifm.uib.no
}

using a monoclonal antibody to ISAV for indirect fluorescent staining (Falk \& Dannevig 1995) or by using reverse transcriptase PCR (Mjaaland et al. 1997, Lovely et al. 1999) for identification of ISAV in infected SHK-1 cells.

Virus production from the mentioned cell lines might vary. For SHK-1 the low yield is reported to be a limiting factor for virus characterization. The virus infective titres obtained by cytopathic effects (CPE) or immunofluorescence (IF) were shown to be $10^{5.4}$ $50 \%$ Tissue Culture Infectivity Dose $\left(\mathrm{TCID}_{50}\right) \mathrm{ml}^{-1}$, but slow and weak cytopathic growth of ISA virus was also reported (Falk et al. 1998). Kibenge et al. (2000) reported that out of 13 isolates, 13 and 6 isolates of ISAV replicated in SHK-1 and CHSE-214 respectively and that the virus titres obtained was highest for SHK-1 showing titres of $10^{7.8} \mathrm{TCID}_{50} \mathrm{ml}^{-1}$ and $10^{6.5} \mathrm{TCID}_{50} \mathrm{ml}^{-1}$ for CHSE-214. There is a need for a well-growing, highly ISAV-sensitive and stable cell line with respect to virus production. In this report we describe a new cell line derived from salmon leukocytes which has a potential for use in diagnostics as well as for antigen production. 


\section{MATERIALS AND METHODS}

Primary cell culture. A head kidney was obtained from unvaccinated Atlantic salmon Salmo salar L. weighting $3 \mathrm{~kg}$ reared in the facilities of The Industrial and Aquatic Laboratory, Bergen, Norway. The fish were kept in $6500 \mathrm{l}$ tanks at a temperature of $8^{\circ} \mathrm{C}$ and with a constant flow rate of saline water of $1.01 \mathrm{~kg} \mathrm{fish}^{-1} \mathrm{~min}^{-1}$. The fish were fed commercial salmon pelleted food dispensed from an automatic feeder $8 \mathrm{~h}$ a day. The fish had no history of previous infectious diseases. The head kidney was removed aseptically, placed in $10 \mathrm{ml}$ of holding medium containing RPMI 1640 (BioWhittaker), $100 \mu \mathrm{g} \mathrm{ml}^{-1}$ gentamicin sulphate (BioWhittaker), $2 \mathrm{mM}$ L-glutamine (BioWhittaker) and 10\% foetal calf serum (FCS) (Gibco BRL) and homogenized. The cell suspension was applied on ficoll gradient (Pharmacia Biotech $\mathrm{AB}$ ) and centrifuged at $1000 \times g$ for $30 \mathrm{~min}$ at $4^{\circ} \mathrm{C}$. The isolated leukocytes were suspended in $30 \mathrm{ml}$ of the holding medium and mixed well with a vortex mixer before centrifugation at $900 \times g$ for $10 \mathrm{~min}$ at $4^{\circ} \mathrm{C}$. The cell pellet was suspended in culture medium containing Eagle's MEM with Earle's BSS, without L-glutamine (EMEM) (BioWhittaker), $200 \mathrm{\mu g} \mathrm{ml}^{-1}$ gentamicin sulphate, $1 \mathrm{\mu g} \mathrm{ml}^{-1}$ fungizone (BioWhittaker), $292 \mu \mathrm{g} \mathrm{ml}^{-1}$ L-glutamine, $50 \mathrm{mM}$ mercaptoethanol (Gibco BRL), 1\% MEM Eagle Non Essential Amino Acid (NEAA) (100×) (BioWhittaker) and 10\% FCS (BioWhittaker). Cells $\left(10^{7.9} \mathrm{ml}^{-1}\right)$ were cultured in $25 \mathrm{~cm}^{2}$ tissue culture flasks (Nunc) at $20^{\circ} \mathrm{C}$ in air with $5 \% \mathrm{CO}_{2}$. Non-adherent cells were removed the next day and fresh culture medium was added. Thereafter, the cells were observed daily and half of the medium was changed approximately every second week. After about 3 mo growing cell layers were observed and these were further cultivated. Cell layers were trypsinated (Trypsin Versene, BioWhittaker) and non-adherent cells were transferred to a new tissue culture flask, where some adherent cells proliferated to new layers.

Cell growth. The subculturing was done as described above and repeated at intervals dependent on growth rates, size of the layer and time after last subculturing. Flasks with a monolayer were split at ratios of 1:2/1:3 at intervals, and after $1 \mathrm{yr}$ in culture they could be split weekly. The cell culture was termed TO. Growth of TO cells without $\mathrm{CO}_{2}$ supplement was performed in media as described above, but Eagle's MEM with Hanks' BSS (HMEM) (BioWhittaker) or L-15 (Leibovitz) (BioWhittaker) replaced EMEM. Cells were frozen by means of a general procedure. A monolayer from a $80 \mathrm{~cm}^{2}$ flask was trypsinated and centrifuged at $168 \times g$ for $5 \mathrm{~min}$ at $5^{\circ} \mathrm{C}$. The pellet was resuspended in freezing medium (30\% FCS, $10 \%$ DMSO [dimethyl sulfoxide, Merck], $60 \%$ EMEM) which was added drop by drop until it totaled $1 \mathrm{ml}$, and then transferred to a cryo tube (1.8 ml, Nunc). The pellet and the medium were held on ice during the whole procedure. The cryo tube was slowly frozen and stored in liquid nitrogen. Thawed cells were centrifuged as described above and transferred to one flask with growth medium. The cells adhered rapidly to the plastic.

Virus strains. The virus strain ISAV HI/92 [Institute of Marine Research (HI), Bergen, Norway], was isolated from Atlantic salmon in a natural outbreak of ISA in 1992. The virus material was kindly provided by Britt Hjeltnes, at the Institute of Marine Research, as frozen whole blood from moribund fish.

Virus infection. Whole blood from moribund fish was centrifuged at $1000 \times g$ for $5 \mathrm{~min}$ and diluted 1:10 in EMEM containing $1 \mathrm{\mu g} \mathrm{ml}^{-1}$ fungizone and $200 \mu \mathrm{g}$ $\mathrm{ml}^{-1}$ gentamicin sulphate and then passed through a filter $(0.2 \mu \mathrm{m}$ pore size, Schleicher \& Schuell). Samples $(10 \mathrm{ml})$ were transferred to each flask $\left(80 \mathrm{~cm}^{2}\right)$ with monolayer of $\mathrm{TO}$ cells and incubated at $15^{\circ} \mathrm{C}$ without $\mathrm{CO}_{2}$. The next day $10 \mathrm{ml}$ culture medium with a double concentration of L-glutamine $\left(584 \mu \mathrm{g} \mathrm{ml}^{-1}\right)$, NEAA $(2 \%)$ and FCS $(10 \%)$ was added and further incubated until cell lysis. The cell lysate was frozen at $-80^{\circ} \mathrm{C}$, centrifuged at $3200 \times g$ for $10 \mathrm{~min}$ and passed through a filter $(0.2 \mu \mathrm{m}$ pore size). Passages in cell culture were performed using the resulting virus solution later termed virus supernatant. The virus supernatant was diluted 1:100 in culture medium without L-glutamine, NEAA or FCS before incubation in $80 \mathrm{~cm}^{2}$ flasks with a monolayer of TO cells. The flasks were incubated at $15^{\circ} \mathrm{C}$ without $\mathrm{CO}_{2}$ until cell lysis.

Virus infectivity. For practical reasons TO cells were tested for growth and subsequent susceptibility and virus production without $\mathrm{CO}_{2}$ supplement. TO cells were split 5 times in media in which HMEM or L-15 replaced EMEM before they were infected with ISAV. The infections were performed in media at $\mathrm{pH} 7$ and at pH 6 using L-15 or HMEM as described for the EMEM. The effects of 15 and $20^{\circ} \mathrm{C}$ were tested using L-15. The virus dose used for infection was $10^{4.6} \mathrm{TCID}_{50} \mathrm{ml}^{-1}$. Four parallel tissue culture flasks were used, and the flasks were incubated with tightened screw caps without $\mathrm{CO}_{2}$. At Day 7 and Day 14 two flasks were harvested and the cell lysate were mixed before $3 \mathrm{ml}$ samples were centrifuged at $3200 \times g$ for $10 \mathrm{~min}$ and filtrated through a $0.45 \mu \mathrm{m}$ Minisart-Plus, cellulose acetate filter (Sartorius AG). The samples were used for calculating the $\mathrm{TCID}_{50}$.

Virus isolation. For virus production $10 \mathrm{ml}$ of 1:100 dilution of the virus supernatant was added to $80 \mathrm{~cm}^{2}$ flasks and incubated until cell lysis, which took place within 7 to $9 \mathrm{~d}$. Resulting virus supernatants could be used at higher dilutions for infection of TO-cells. ISAV was isolated from about $220 \mathrm{ml}$ cell lysate. The cell lysate was centrifuged at $3200 \times g$ for $10 \mathrm{~min}$, and $36 \mathrm{ml}$ 
supernatant was then transferred to each centrifuge tube $(25 \times 89 \mathrm{~mm}$, Ultra clear, Beckman) containing $1.0 \mathrm{ml}$ of $65 \%$ sucrose in TNE-buffer $(0.01 \mathrm{M}$ Tris, $0.1 \mathrm{M} \mathrm{NaCl}, 0.001 \mathrm{M}$ EDTA, pH 7.2). Virus was isolated from the bottom of the tube after centrifugation at $102900 \times g$ for $1 \mathrm{~h}$ at $4^{\circ} \mathrm{C}$. A total of $34 \mathrm{ml}$ of supernatant was removed from the top of the tube. The remaining $3 \mathrm{ml}$ from each of 2 tubes were mixed and gently placed on top of a continuos sucrose gradient 25 to $65 \%$ in a $14 \times 89 \mathrm{~mm}$ tube (Ultra clear, Beckman). The sucrose gradient was centrifuged at $212100 \times g$ for $20 \mathrm{~h}$ at $4^{\circ} \mathrm{C}$. Virus material was isolated from 3 gradient tubes by pipetting $1.5 \mathrm{ml}$ from the visible band in the gradient. These were mixed and suspended in TNE buffer before centrifugation at $291000 \times g$ for $1 \mathrm{~h}$ at $4^{\circ} \mathrm{C}$. The pellets containing virus were resuspended in $600 \mu \mathrm{l}$ PBS. This solution is later termed virus stock solution.

TCID $_{50}$. 24-well tissue culture plates (Nunclon) with a monolayer of TO-cells were used for $\mathrm{TCID}_{50}$. Virus dilutions were made in EMEM supplied with $50 \mu \mathrm{g}$ $\mathrm{ml}^{-1}$ gentamicin sulphate. Six parallels were made of each dilution and $500 \mu \mathrm{l}$ was added to each well. Tissue culture plates were placed in open sample bags of polyethylene (Minigrip ${ }^{\circledR}$ ) to ensure enough humidity. The plates were incubated at $15^{\circ} \mathrm{C}$ for $24 \mathrm{~h}$ with $5 \%$ $\mathrm{CO}_{2}$ in air before $500 \mu \mathrm{l}$ EMEM supplied with $584 \mu \mathrm{g}$ $\mathrm{ml}^{-1}$ L-glutamine, $50 \mu \mathrm{g} \mathrm{ml}^{-1}$ gentamicin sulphate, $2 \%$ Eagle's MEM NEAA and 10\% FCS were added to each well. Wells with CPE (e.g. vacuolization and loss of adherence) at Day 14 after infection were considered infected. TCID $_{50}$ was estimated according to Kärber (1931).

Antigen characterization. SDS-PAGE resolutions of the virus proteins and TO-cell proteins were performed according to the method of Laemmli (1970) with minor modifications as described by Tsang et al. (1983). Two ISAV stock solutions, which were purified separately (termed ISAV stock solution I and II) were diluted 1:2 or 1:5 in sample buffer before being added to the gel. TO cells from an $80 \mathrm{~cm}^{2}$ tissue culture flask with monolayer were harvested by trypsination and washed once in HMEM prior to suspension in $500 \mu \mathrm{l}$ distilled water. This cell solution is termed TO cell stock solution. TO cell stock solution diluted 1:32 in sample buffer was applied to 1 well. Ten $\mu$ of samples and $5 \mu$ Low Range Protein Standard (Bio-Rad) diluted 1:100 in sample buffer were applied to respective wells in a $12.5 \%$ gel in a Mini Protean II xi slab cell (BioRad). The proteins were verified by silver staining according to Switzer et al. (1979).

Challenge experiment. Non-vaccinated salmon with no previous history of infectious diseases from veterinary controls were provided by Alvøen Settefisk, Norway.
Each group consisted of 30 individuals with a weight of $58 \pm 9 \mathrm{~g}$ (mean $\pm \mathrm{SD}$ ) and was held in a $150 \mathrm{l}$ dark fibreglass tank with a constant seawater flow of 2.01 $\mathrm{min}^{-1} \mathrm{~kg}^{-1}$ fish. Water temperature was $10^{\circ} \mathrm{C}$ and the fish were fed ad libitum twice a day. Acclimatization took place 2 wk before the experiment started. Cell lysate from ISAV-infected TO cells, harvested on Day 9 was centrifuged at $3000 \times g$ for $10 \mathrm{~min}$ and filtered $(0.2 \mu \mathrm{m}$ pore size). Six different dilutions of ISAV supernatant $\left(10^{6.83}\right.$ TCID $\left._{50} \mathrm{ml}^{-1}\right), 1: 10,1: 50,1: 100,1: 200,1: 500$ and 1:1000, were used in the challenge and dilutions were done in EMEM. Salmon were starved for $24 \mathrm{~h}$ and anaesthetized in $0.03 \%$ chlorobutanol prior to intraperitoneally injection with $0.1 \mathrm{ml}$ virus dilution. Two control groups received 2 different dilutions (1:10 and 1:1000) of culture supernatant from uninfected TO cells and the fish were treated as described above. Dead and moribund salmon were removed daily and samples were collected from lethargic fish for reisolation of ISAV and measuring of hematocrit. Hematocrit was determined within 30 min of sampling using heparinized haematocrit capillary tubes and centrifuged for $5 \mathrm{~min}(19872 \times g)$ in haematocrit centrifuge (Jouan A 13, ALC).

\section{RESULTS}

\section{Cell culture}

During the first 3 mo there were critical periods for cell growth with few live cells. Growth was slow when the cell clusters contained few cells but improved as cell numbers and number of subcultures increased. The morphology of the cells changed. In the beginning the detachment of the cells from the colony and the plastic caused by trypsination was critical due to both fragility of the cells and the low cell number. As cell numbers and subcultures increased, the cells grew faster and trypsination was easier with less cell death. Single cells or cells at the edge of the colony were enlarged, with long pseudopodial protrusions. In confluent cultures the cells do not have these characteristics but appears to be rounded. After several subcultures the trypsinated cells rapidly attached to the flask (polystyrene) and formed colonies.

More than 150 subcultures of the TO cells were grown and they could be split (1:2 or 1:3) weekly, but maintain in good shape for long periods even at high densities and rapid growth occurred after trypsination. TO cells at Days 1, 3 and 6 following subculture are shown in Fig. 1. The cells did not show any visible morphological changes after 5 subcultures in HMEM or L-15, but appeared to grow slightly faster in the HMEM medium than in the L-15 medium. Cells stored in liquid nitrogen grew rapidly after thawing. 


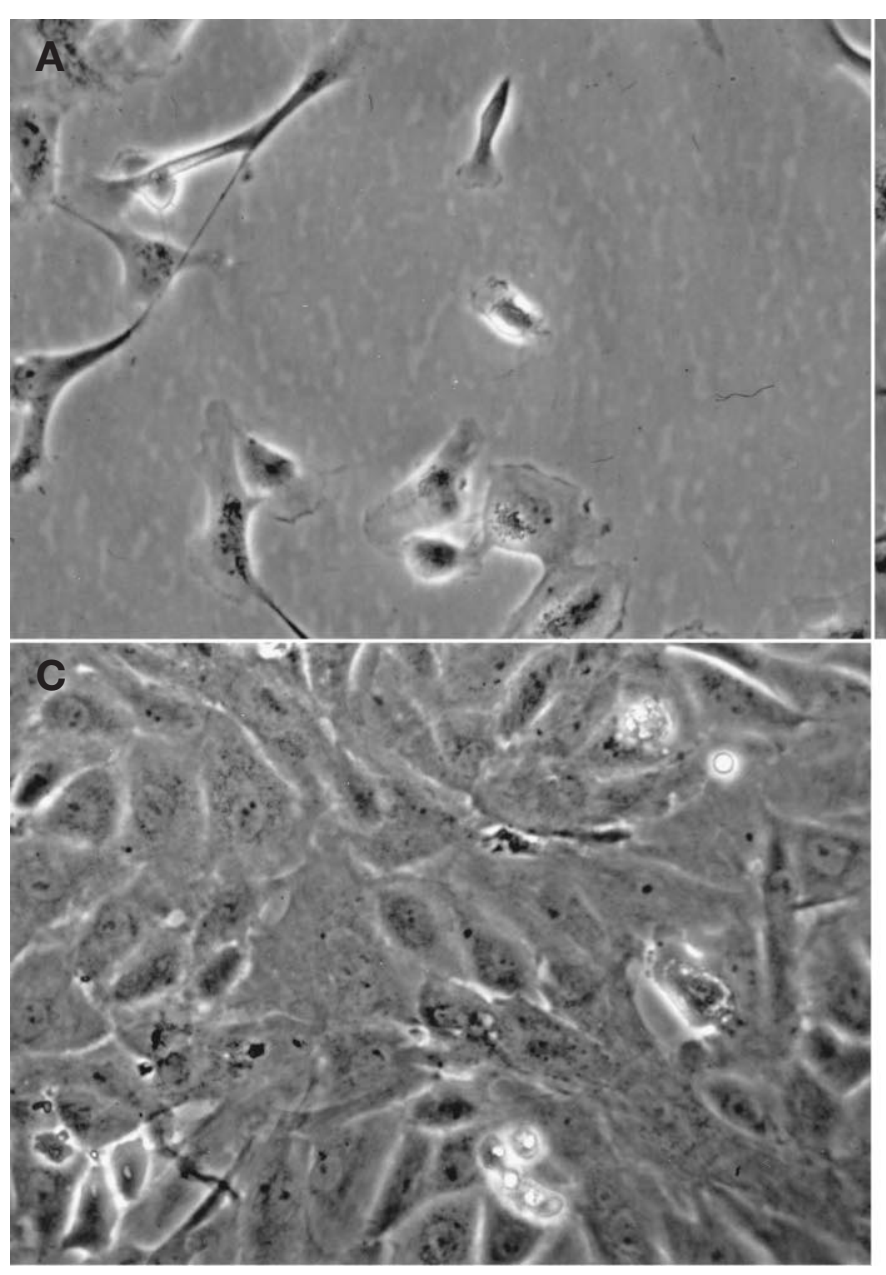

ISAV production

After $3 \mathrm{~d}$ post infection of TO cells with ISAV, vacuoles were observed in single cells or cell clusters and the cell culture was completely lysed or cells were detached within $9 \mathrm{~d}$. The time from infection to CPE was constant and remained unchanged with different growth media and no unsuccessful infection took place. Frozen cells were easily grown and no changes in susceptibility or virus production were observed. ISAV-infected cell cultures at Days 3, 6 and 9 are shown in Fig. 2. The virus titre using these growth media was determined after 5 subcultures. The cells were passed about 40 times in HMEM medium and no changes with respect to growth rate, morphology or virus sensitivity were observed.

Virus supernatant harvested $12 \mathrm{~d}$ post infection reached an infectivity titre of $10^{9.1} \mathrm{TCID}_{50} \mathrm{ml}^{-1}$ and, when tested after freezing, it had decreased to $10^{7.6} \mathrm{TCID}_{50} \mathrm{ml}^{-1}$. Both cell lysates were centrifuged at $3200 \times g$ for $10 \mathrm{~min}$ and filtered $(0.2 \mu \mathrm{m}$ pore size) before performing the $\mathrm{TCID}_{50}$ test. In general, the $\mathrm{TCID}_{50}$

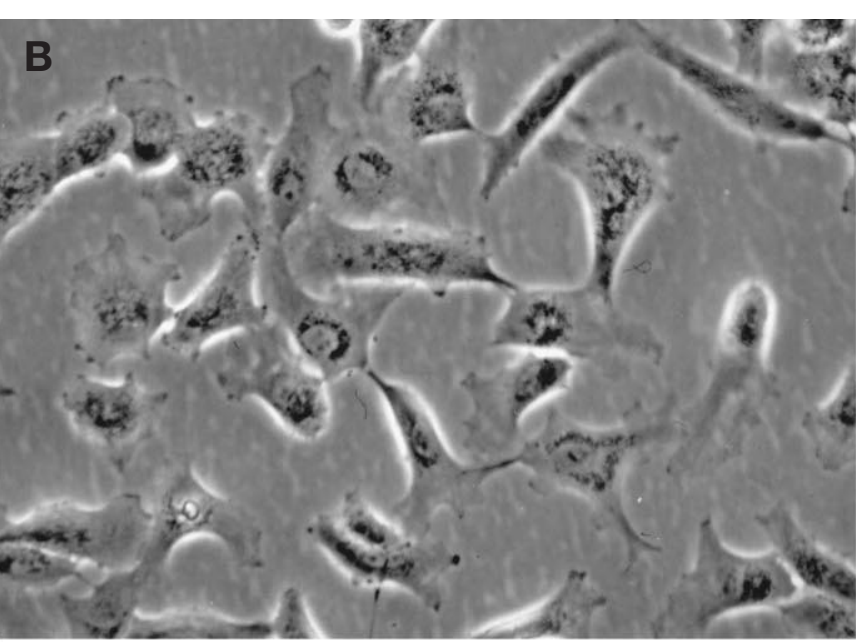

Fig. 1. TO cells at (A) $1 d$, (B) $3 d$ and (C) $6 \mathrm{~d}$ after splitting to low density. Magnification, $\times 200$

did not change from Day 9 to 14 after infection, though a slight increase was sometimes observed. Some differences in virus titres $\left(10^{7.8}\right.$ to $\left.10^{9.1}\right)$ were observed during different analyses, as the cell densities probably varied.

Virus production was reduced when the initial $\mathrm{pH}$ in the medium was 6 as compared to $\mathrm{pH} 7$ for both cells grown in L-15 and in HMEM. The low virus titres of infected cells that were incubated at $20^{\circ} \mathrm{C}$ indicated that virus was not produced at this temperature. The results are summarised in Table 1, and cells grown in HMEM at pH 7 provided virus titres comparable with those obtained using EMEM.

\section{ISAV protein profile}

Protein profiles of isolated virus (stock solution I) showed 3 distinct protein bands, at molecular weights (MW) of 40 to 48 and 2 others at 53 and $71 \mathrm{kDa}$. In addition, some bands located above $53 \mathrm{kDa}$ were present. Further, a distinct band at $26 \mathrm{kDa}$ was found, and some low MW bands appeared between 14 and $21 \mathrm{kDa}$. 

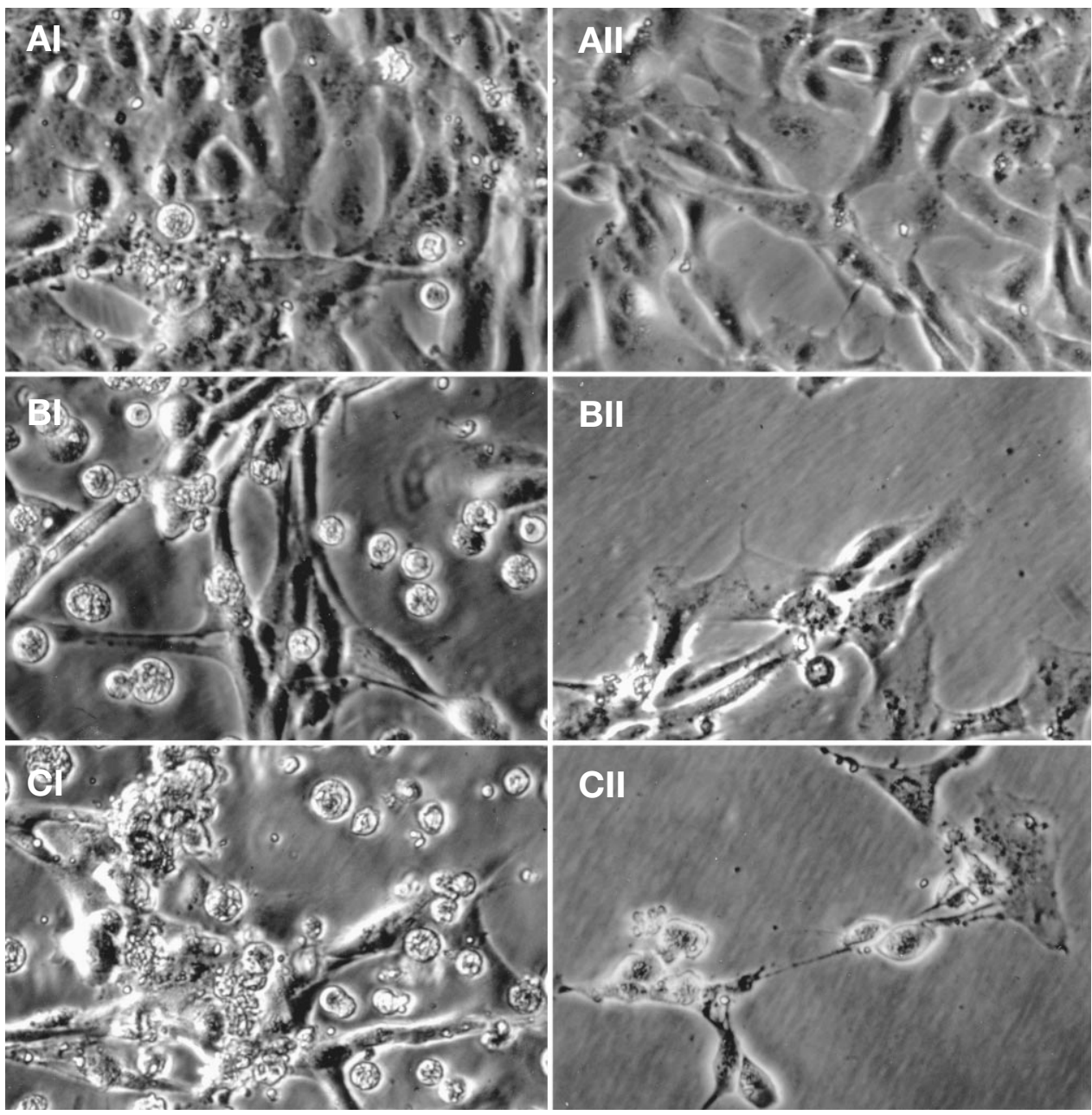

Fig. 2. TO cells after infection with virus supernatant containing ISAV. Virus supernatant had been frozen, centrifuged, filtered and diluted 1:100. (AI) $3 \mathrm{~d}$ after infection. Note presence of a few round cells in the medium and areas without cells. (AII) Same preparation as in (AI) but growth medium has been removed. Note presence of numerous vacuoles in neighbouring cells, the first visible sign of CPE. (BI) $6 \mathrm{~d}$ after infection. Note many rounded cells in the medium. (BII) Same preparation as in (BI) but growth medium has been removed. Note extended cell-free areas. (CI) $9 \mathrm{~d}$ after infection. Note large number of cells and amount of cell debris in the growth medium. (CII) Same preparation as in (CI), but growth medium has been removed. Magnification, $\times 200$

The protein profile is shown in Fig. 3. The protein bands resulting from a different purification batch of the same ISAV isolate (virus stock solution II) is shown in Fig. 3B, lane 2. The protein bands in region 55 to $65 \mathrm{kDa}$ are more separated, showing 2 bands, since the gel was run for a longer time. The lowest MW bands do not appear for the same reason. The protein profile of uninfected TO cells is shown in Fig. 3B, lane 1.

\section{Challenge experiments}

In the challenge experiment performed with virus supernatants, mortality started $14 \mathrm{~d}$ after challenge.
Table 1. The ISAV production by cells grown without $\mathrm{CO}_{2}$ shown by $\mathrm{TCID}_{50}$

\begin{tabular}{|lcccc|}
\hline Medium & $\begin{array}{c}\text { Temperature } \\
\left({ }^{\circ} \mathrm{C}\right)\end{array}$ & $\mathrm{pH}$ & $\begin{array}{c}\text { Day } 7 \\
\text { TCID }_{50} \mathrm{ml}^{-1}\end{array}$ & $\begin{array}{c}\text { Day 14 } \\
\text { TCID }_{50} \mathrm{ml}^{-1}\end{array}$ \\
\hline L-15 & 15 & 7 & $10^{-7.0}$ & $10^{-7.1}$ \\
L-15 & 20 & 7 & $10^{-4.3} \mathrm{a}$ & $10^{-1.0}$ \\
L-15 & 15 & 6 & $10^{-3.0}$ & $10^{-3.8}$ \\
L-15 & 15 & 7 & $10^{-7.1}$ & $10^{-8.0}$ \\
HMEM & 15 & 6 & $10^{-5.5}$ & $10^{-5.8}$ \\
HMEM & 15 & 7 & $10^{-7.1}$ & $10^{-7.8}-10^{-9.1 \mathrm{~b}}$ \\
a CPE was not observed at this dilution, which was the \\
lowest dilution tested \\
b This observation was made at Day 12 \\
\hline \multicolumn{5}{l}{} \\
\hline
\end{tabular}



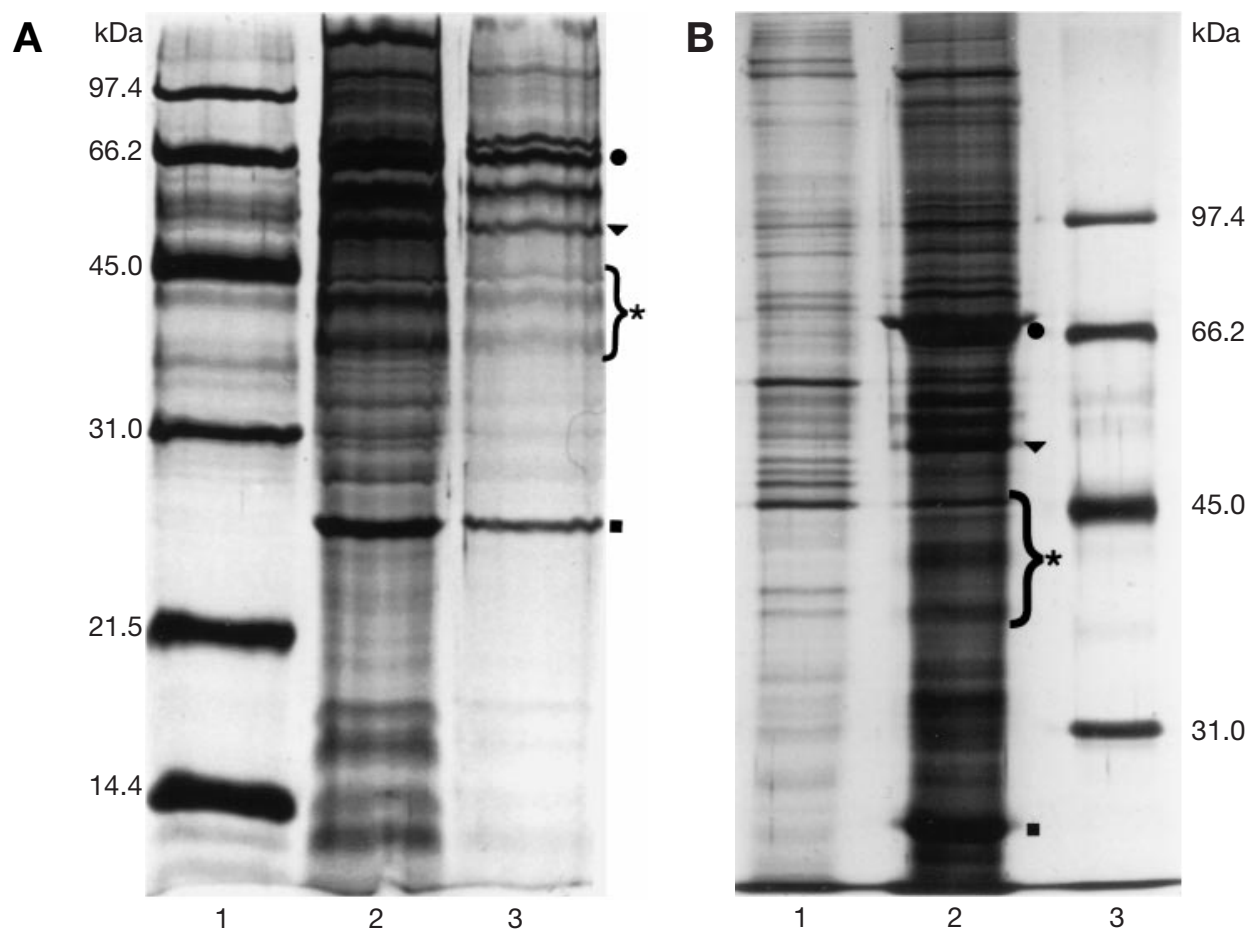

Fig. 3. Silver stained protein profile (SDS-PAGE) of purified ISAV and TO cells. (A) Molecular weight standard diluted 1:100 $(5 \mu \mathrm{l})$ (lane 1), ISAV stock solution I diluted 1:2 (10 $\mu \mathrm{l}$ sample) (lane 2) and ISAV stock solution I diluted 1:5 (10 $\mu \mathrm{l}$ sample) (lane 3). (B) Uninfected TO cells stock solution diluted 1:32 (10 $\mu$ l) (lane 1), purified ISAV stock solution II diluted 1:5 (10 $\mu \mathrm{l})$ (lane 2) and molecular weight standard diluted 1:100 (5 $\mu \mathrm{l})$ (lane 3). Positions of some viral proteins are indicated with symbols $\left(26 \mathrm{kDa}: \mathbf{\square}^{\prime}\right.$ 40 to $48 \mathrm{kDa}$ : *; $53 \mathrm{kDa}: \mathbf{\nabla}$; and $71 \mathrm{kDa}: \bullet)$
Mortality rate correlated with the injected virus dilution, resulting in the highest mortality for those receiving the lowest dilutions. The mortality for all groups was between 90 and $100 \%$ at termination of the experiment (Fig. 4). Dead and moribund salmon showed clinical signs of ISA, and hematocrit values of lethargic fish were $19.6 \% \pm 10.3$ (mean $\pm \mathrm{SD}, \mathrm{n}=8$ ). Virus was reisolated from the diseased fish as diluted blood caused characteristic CPE in individual cells and cell clusters were observed from the third day on and later resulted in cell detachment and complete cell lysis.

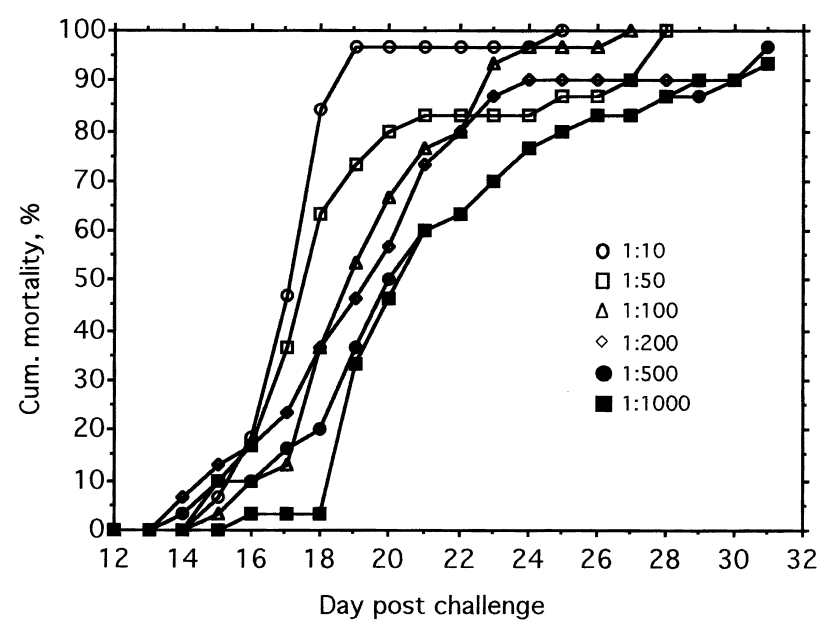

Fig. 4. Cumulative mortality of Atlantic salmon Salmo salar L. after injection with virus supernatant from ISAV-lysed TO cells

\section{DISCUSSION}

The growth rate of the TO cell line is relatively good, as subcultures are performed in ratios 1:2 or higher at $7 \mathrm{~d}$ intervals. Cell establishment and initial growth occurred in the presence of $\mathrm{CO}_{2}$, but the growth rate did not decrease without $\mathrm{CO}_{2}$ supplement using either HMEM or L-15 media with buffers controlling the initial $\mathrm{pH}$ at 7 and using $20^{\circ} \mathrm{C}$ for cultivation. At present the TO cells have been subcultured about 150 times. The cells grow well after freezing at $-80^{\circ} \mathrm{C}$. No differences in growing abilities or morphology were observed after the first 15 to 20 subcultures.

The sensitivity of TO cells for ISAV was verified by the presence of CPE in infected cell cultures. Vacuolization of individual cells and cell clusters was observed from the third day on and resulted later in cell detachment and complete cell lysis. This CPE characteristics have remained unchanged throughout our work. An infectivity titre of $10^{9.1} \mathrm{TCID}_{50} \mathrm{ml}^{-1}$ was obtained with centrifuged and filtered fresh virus supernatant collected on $12 \mathrm{~d}$ post infection of cells. The titre was about 100 times higher compared with virus supernatant harvested $7 \mathrm{~d}$ post infection. The virus titre dropped when the virus supernatant had been frozen, but it was highly infective both for the TO cells and salmon.

The virus titres were determined in our studies by CPE to be between $10^{7.8}$ and $10^{9.1} \mathrm{TCID}_{50} \mathrm{ml}^{-1}$ using TO cells. This was as high or higher than the titres de- 
termined by IF on ISAV infected SHK-1 cells $\left(10^{6}\right.$ to $10^{7}$ ) (Falk et al. 1997) and in both SHK-1 $\left(10^{5.5}\right.$ to $\left.10^{7.8}\right)$ and CHSE-214 $\left(10^{4.5}\right.$ to $\left.10^{6.5}\right)$ determined by Kibenge et al. (2000). The virus supernatants in our studies were centrifuged and filtered to remove cell debris. Kibenge et al. (2000) did not filtrate the virus solution tested. The filtration step in our study might have reduced the virus titre, and thus the difference in titres might be greater than observed. For production of infective particles, budding from the cell membrane must be completed (Dannevig et al. 1995a), as the ISA virus has characteristics of Orthomyxoviridae (Falk et al. 1997). The rounding of cells and the presence of cell debris was clearly seen in the cell lysate, and thus much virus material was probably removed from the lysate by centrifugation and filtration. When ISAV was produced in CHSE-214 cells, the cellassociated virus titre was 10 times higher than cell-free virus titre (Kibenge et al. 2000), and one cannot exclude the possibility that this is also the case for TO cells.

Increased concentration of virus might be obtained using a smaller volume of medium per infected flask. Further studies could show whether changing other variables increases the outcome of virus components. Virus titres obtained by use of TO cells are higher than those obtained when a range of cell lines was used for production of sea bream iridovirus $\left(10^{2.5}\right.$ to $10^{5.5} \mathrm{TCID}_{50}$ $\mathrm{ml}^{-1}$ ) (Nakajima \& Sorimachi 1994). It is also as high as titres of infectious pancreas necrosis virus (IPNV) obtained from CHSE-214 cells $\left(10^{7}\right.$ to $\left.10^{8} \mathrm{TCID}_{50} \mathrm{ml}^{-1}\right)$ (Hedrick et al. 1978). However, the amount of virus cannot be directly correlated with titres, as both cell lines and virus type varies and the number of virus particles necessary for both infection and lysis of different cell lines are seldom known.

Compared with the SHK-1 cells, TO cells produced a high yield of ISAV shown by the low volume used for isolation, and the fact that polyethylene glycol (PEG) precipitation was not necessary.

The isolation of ISAV from virus supernatants took place by first concentrating the ISAV material on a $65 \%$ sucrose layer before purification on a continuos sucrose gradient. The protein profiles in SDS-PAGE showed clear protein bands and the MW of the bands are mainly in accordance with those found by Falk et al. (1997) and Kibenge et al. (2000). One cannot exclude the possibility that the bands in region 55 to $65 \mathrm{kDa}$ are of cell origin, as Kibenge et al. (2000) suggested for a band in the same region (66 kDa). This protein pattern was reproduced from different batches of isolated virus. A distinct band has always appeared at about $26 \mathrm{kDa}$. Low molecular protein bands, comparable with those observed by Kibenge et al. (2000), were present. They suggested that polypeptides of this size were of non-viral origin based on similar bands in other virus isolates and non-infected cells. For complete comparison, isolates should be analysed in the same assay and isolated by the same procedure. Variations might exist between isolates and Kibenge et al. (2000) identified minor variations in protein profiles between 2 Canadian ISAV isolates. Also, genomic sequence data have shown differences between isolates of Norwegian, Canadian and Scottish ISAV (Blake et al. 1999, Cunningham \& Snow 2000). The volume of virus supernatant used to provide material for the protein profiles of purified virus indicated a high virus production from the TO cells. The ISAV-containing material from SHK-1 cells has to be concentrated by PEG before purification due to the high volume of cell lysate (Falk et al. 1997). The exact amount of cell lysate required for virus isolation from SHK-1 cells is not reported in the presented purification protocols. Further study is needed to determine the optimal time and infection procedure for harvesting cell lysate with respect to obtaining more virus antigen and infective particles. Another important aspect is sensitivity of TO cells various ISAV isolates. The amount of antigen produced by the reported procedure is completely sufficient for virus characterisation and studies of immune responses to ISAV in salmon.

Acknowledgements. This work was supported by Alpharma AS.

\section{LITERATURE CITED}

Blake S, Bouchard D, Keleher W, Opitz M, Nicholson BL (1999) Genomic relationships of the North American isolate of infectious salmon anaemia virus (ISAV) to the Norwegian strain of ISAV. Dis Aquat Org 35:139-144

Bouchard D, Keleher W, Opitz HM, Blake S, Edwards KC, Nicholson BL (1999) Isolation of infectious salmon anemia virus (ISAV) from Atlantic salmon in New Brunswick, Canada. Dis Aquat Org 35:131-137

Cunningham CO, Snow M (2000) Genetic analysis of infectious salmon anaemia virus (ISAV) from Scotland. Dis Aquat Org 41:1-8

Dannevig BH, Falk K, Namork E (1995a) Isolation of the causal virus of infectious salmon anaemia (ISA) in a longterm cell line from Atlantic salmon head kidney. J Gen Virol 76:1353-1359

Dannevig BH, Falk K, Press CMcL (1995b) Propagation of infectious salmon anaemia (ISA) virus in cell culture. Vet Res 26:438-442

Falk K, Dannevig BH (1995) Demonstration of infectious salmon anaemia (ISA) viral antigens in cell cultures and tissue sections. Vet Res 26:499-504

Falk K, Namork E, Rimstad E, Mjaaland S, Dannevig BH (1997) Characterization of infectious salmon anaemia virus, an Orthomyxo-like virus isolated from Atlantic Salmon (Salmo salar L.). J Virol 71:9016-9023

Falk K, Namork E, Dannevig BH (1998) Characterization and applications of a monoclonal antibody against infectious salmon anaemia virus. Dis Aquat Org 34:77-85

Hedrick RP, Leong JC, Fryer JL (1978) Persistent infections 
in salmonid fish cells with infectious pancreatic necrosis virus (IPNV). J Fish Dis 1:297-308

Kärber G (1931). Beitrag zur kollektiven Behandlung pharmakologischer Reihenversuche. Naunyn-Schmiedebergs Arch Pharmakol Exp Pathol 162:480-483

Kibenge FSB, Lyaku JR, Rainnie D, Hammell KL (2000) Growth of infectious salmon anaemia virus in CHSE-214 cells and evidence for phenotypic differences between virus strains. J Gen Virol 81:143-150

Laemmli UK (1970) Clevage of structural proteins during the assembly of the head of bacteriophage T4. Nature 227: 680-685

Lovely JE, Dannevig BH, Falk K, Hutchin L, MacKinnon AM, Melville KJ, Rimstad E, Griffiths SG (1999) First identification of infectious salmon anaemia virus in North America with haemorrhagic kidney syndrome. Dis Aquat Org 35: 145-148

Mjaaland S, Rimstad E, Falk K, Dannevig B (1997) Genomic characterization of the virus causing infectious salmon

Editorial responsibility: Jo-Ann Leong,

Corvallis, Oregon, USA anaemia in Atlantic salmon (Salmo salar L.): an orthomyxo-like virus in a teleost. J Virol 71:7681-7686

Nakajima K, Sorimachi M (1994) Biological and physicochemical properties of the iridovirus isolated from cultured red sea bream, Pagrus major. Fish Pathol 29:29-33

Roger HD, Turnbull T, Muir F, Millar S, Ricards RH (1998) Infectious salmon anaemia (ISA) in United Kingdom. Bull Eur Assoc Fish Pathol 18:115-116

Sommer AI, Mennen S (1997) Multiplication and haemadsorbing activity of infectious salmon anaemia virus in the established Atlantic salmon celline. J Gen Virol 78: 1891-1895

Switzer RC III, Merril CR Shifrin S (1979). A highly sensitive silver stain for detecting proteins and peptides in polyacrylamide gels. Anal Biochem 98:231-237

Tsang VCW, Peralta JM, Simons AR (1983) Enzyme linked immunoelectrotransfer blot techniques (EITB) for studying the specificities of antigens and antibodyes separated by gel electrophoresis. Methods Enzymol 92:377-391

Submitted: August 21, 2000; Accepted: January 19, 2001

Proofs received from author(s): March 19, 2001 